\title{
LOCAL GOVERNMENT IN SERBIA: BETWEEN LEGISLATION AND PRACTICE
}

\author{
Snežana Vujadinović*1, Dejan Šabićc*, Mirjana Gajić* \\ * University of Belgrade - Faculty of Geography, Belgrade
}

\begin{abstract}
The paper is based on an assumption that there are many limitations of accelerating the decentralization process and the implementation of sustainable development policy in Serbia at the local level. Although these limitations may vary between local governments (local communities) because of different degrees of socialeconomic development, a framework can be defined, which will be explained on the example of Serbia as a developing country. Lately, the role and the importance of the local community has been strengthening, which is particularly intensified by the rapid technical and technological development and the need for a quick adjustment to the changes resulting from it. In this regard, the development of local government units and the level of living standard of citizens increasingly depend on the modernization of local government legislation. The issue of property and resources management at the local level is essential for the process of decentralization, economic empowerment and the development of local government. The article is and a discussion aimed at the development capacity and the problems of local government units and their ability to initiate the process of democratization and economic prosperity of the country, given the numerous development limitations (economic, social and environmental), and the inherited patterns of behavior from the time of socialism.
\end{abstract}

Key words: local government, legislation, municipality, city, development, participation, social capital

\section{Introduction}

In the development of every person, the local geographic environment plays an important role because of their space orientation, a sense of safety and of belonging to the community and to the place where they live or where

\footnotetext{
${ }^{1}$ Correspondence to: vujadinovicsnezana@gmail.com
} 
they perform their activities. In other words, one needs to belong to a particular social group inhabiting an area, or performing certain activities in an area, because this is something that distinguishes them from the rest of the world ("belongs where he was born" or "belongs where he works") and marks their individuality. Common interests, intense interaction between the people and the existence of possibilities of satisfying their basic needs within their own community (village, town, municipality), are conditions and consequences of creating the local identity. The degree of cultural, social and functional local integration is higher if people are more connected with their immediate surroundings, and if a desire to remain in their place or municipality is present (Vujadinović et al., 2010).

The European Charter of Local Government (1985), the most important European document on local government, defines the concept of local government, in Article 3. It states that local government signifies the right and the ability of local authorities, to regulate and manage a substantial share of public affairs, acting within the limits of the law, under their own responsibility in the interest of the local population (Mujović, 1997). Local government is the most important aspect of decentralization, namely the only real decentralization (Vučetić, 2006). It is an autonomous system of management of local communities constituted on the narrower parts of the country's territory.

The term used in Serbia is lokalna samouprava, in Germany - Selbstverwaltung, in Great Britain - self government and local government, in Russia - samoupravlenie, in France administration locale, in Switzerland - Gemeindedemokratie (Djurdjev, 1997).

Each local community in Serbia has a specific problem that can not be solved, in political system, in which many the decisions are made at a single center of power. One of the main problems of centralized countries is their inability to realize and respond to the essential local problems and needs, and to identify the local resources that can be used to improve the quality of life. Local authorities are the key bearers of economic activities supporting economic growth and development and increasing competitiveness of the local economy.

\section{Methodology and Data}

In terms of methodology, the paper is based on an analysis of legislation in Serbia as the legal basis of local government functioning. The analysis includes a critical examination of the laws passed after the change of the political regime in Serbia in 2000, which regulate the organization of the local 
government authorities (Law on Territorial Organization of the Republic of Serbia, Law on Local Self-Government and the Law on Local Government Finance), a comparison of changes of certain legal regulations and the effects achieved by these changes. For a more comprehensive consideration of evaluation of legislation and of practical results, other important documents were analyzed (European Charter of Local Government, the Constitution of the Republic of Serbia and the Strategy for Municipal Development in Serbia).

In order to examine the unbalanced development of Serbia and to analyze the socioeconomic and demographic indicators, we used statistical data by the Statistical Office of the Republic of Serbia.

\section{Previous studies}

The issues of defining local government and of legislation defining local government were dealt with by numerous foreign (Loughlin 1996, Goldsmith 1990) and local authors (Ilić 1996, Djurdjev 1997, Lilić 1999, Blagojević 1997, Davitkovski 1997, Kuzmanović 1999, Dimitrijević 1999, Milenković 2000, Vučetić 2006, Jovanović et al. 2011, Milosavljević 2005; 2009, Mirić 2009,); of participation, i.e. active involvement of the citizens in the public life of the local community (Pušić 2001, Vukelić 2009, Vujošević 2008, Milosavljević 2006), of social capital (Ostrom 1993, Jacobs 1961, 1993, 1997, Coleman 1988; Putnam et al., 1993, Bourdie 1985, Putnam 1995, Lee, Arnason i dr., 2005, Shucksmith 2000, Roseland 2000, Cvejić 2004, Begović 2006, Vujošević 2008, Petovar 2008), of local economic development (Janković 2007, Pavlović-Križanić 2010, Ateljević et al. 2011, Belkić, et al. 2010) and others.

\section{Results}

\section{Legal basis for local government functioning}

Although the decentralization has been one of the priorities in the development of the country and moving towards the European integrations since the democratic changes in Serbia in 2000, Serbia is, according to Vučetić (2006), one of the most centralized European countries. This is suggested by the organization of government (most of the jurisdiction is at the national level), by demographic and economic characteristics (high polarization in the distribution of the population and the capital) etc. The centralization of 
Serbia can be noticed in the dualism: Belgrade agglomeration - the rest of the country. Negative economic, demographic and infrastructural consequences of a rapid population growth of the Belgrade metropolitan area, as the main phenomenon of the centralization, are more and more present.

In the last ten years, the legislation relating to local government has qualitatively changed. The legal regulations and the practical experiences at the local level, showed that the strengthening of local government is not only the extension of jurisdiction, but also the financial autonomy and the use of their own resources in order to stimulate socioeconomic development.

According to the Law on Territorial Organization of the Republic of Serbia (Official Gazette RS, no. 129/07 and 83/2014), the territorial organization of Serbia consists of municipalities, towns, the city of Belgrade as a territorial unit, two autonomous provinces of Vojvodina and Kosovo-Metohia, as a form of territorial autonomy. Serbia has a total of 174 local government units, including 150 municipalities, 23 cities and the city of Belgrade with 17 municipalities. The local government unit is a natural and geographic territorial unit. At the same time, it is also an economic whole associated with the central settlement that is the gravitational center for other settlements.

The law that regulates the system of local government in Serbia, was first passed in 1999 (Official Gazette RS, no. 49/99), and the second time in 2002 (Official Gazette RS, no. 9/02). The present system of local government in Serbia is regulated by the Law on Local Self-Government (Official Gazette RS, no. 129/07 and 83/2014). It is one of the fundamental laws of the country. All the mentioned laws were developed in accordance with the Constitution of the Republic of Serbia and the European Charter of Local Government.

The first Law on Local Self-Government in Serbia in 1999 was characterized by centralist tendencies that led the further strengthening of the central government in relation to the local government (Milenković, 2000). Due to the bad results in practice and the necessity of creating a modern, democratic and open society, there was a need to improve it and simultaneously to comply it with European trends and the European Charter of Local Government.

The Law on Local Self-Government in 2002 regulated all the issues of vital importance for the functioning of the local government, as well as strengthening the decentralization process. However, many solutions (e.g. issue of relation between the Assembly and the Mayor / Municipality president) caused confusion and problems in practice, so the functioning of local authorities was difficult. 
The new Law on Local Self-Government in Serbia systematically regulated the issues of importance to the local government system. Particularly important is the fact that this law established a broad independent scope of local government units, which created the conditions for strengthening the decentralization process. The system that was placed by this law is fully compliant with the European Charter of Local Government, which Serbia signed and ratified (Law on Ratification of the European Charter of Local Government, Official Gazette RS, no. 70/07).

According to the Law on Local Self-Government, Article 2, local government, is the right of citizens to manage the public affairs of immediate, collective and general interests for the local population, directly and through their freely elected representatives in the local government units, as well as the right and the ability of the local government, within the limits of the law, to regulate and manage public affairs under their jurisdiction and of interest to the local population. "Local government is the level of government closest to the citizens, where the citizens can, through their institutions, run the affairs of importance to their community. The issues of existence and the basic conditions of life are most clearly perceived in the local government units because they are, after the family, the second most important community for an individual.

The local environment is a dynamic category. Changes in its structure and physiognomy are most quickly entered by social, but also by sociopsychological, elements and factors, related to the experience of individuals who live in that area, and to the collective connection of the population to the whole (Vujadinović et al 2010). Most issues of key importance for the lives of citizens are solved at the local level of administration - communal services, spatial planning, environmental protection. According to Mirić (2009), more than $60 \%$ of laws are applied at the local level in EU.

According to Loughlin (1996), a modern local government is characterized by multi-functionality (closely connected with the idea of selfsufficiency), the discretionary rights (which are related to the innovative capacity of local governments), independent taxing powers, representation (the only state institution, except for Parliament, which is the subject of periodic direct authorization by the voters).

Local authorities have a central role in providing sustainable development of local areas and better management. Such a role needs the local authorities to have a more energetic and integrated approach to the establishment of local policies, through a harmonization of economic, social, environmental and other development goals. The task of the local govern- 
ment is to activate the citizens, social and non-governmental organizations, companies and associations, in order to have an active role in an integrated local development planning.

The main objectives of the development of local government units are improving the quality of life through new jobs and by integrating local communities into a wider social system (health, educational, cultural institutions), creating a network of relations and cooperation of different actors (from the state and public sector to private enterprises, local authorities and local associations), defining policies of education, scientific research, cultural creativity, sports, information, housing, health and social care, and socioeconomic integration of vulnerable social groups (the disabled, single mothers, refugees and displaced persons, the Roma, etc.), crime prevention, improving the level of safety, environmental improvement, and more.

Local government in Serbia is realized within local government units (municipalities, cities and city of Belgrade). According to the Law on Local Self-Government (Article 18; 23), a municipality is a basic territorial unit in which the local government is exercised, with at least 10,000 inhabitants, while the city is a local government unit that is the economic, administrative, geographic, and cultural center of a wider area and with more than 100,000 inhabitants. Municipal bodies are Municipality Assembly, Municipality President / the Mayor, Municipality Council and Municipality Administration. Local government units carry out the tasks, that are either their original or delegated duties. The original duties of the municipality include the tasks of adoption of development program and budget, urban planning and construction, communal services, construction land maintenance, public transport and protection of natural resources and environment. The municipality is the founder of social care institutions, institutions and organizations in the area of primary education, culture, primary health care, physical education, sport, child protection, tourism and more. Furthermore, the municipality establishes buffer stock to meet the needs of the local population, ensures the protection and the realization of personal and collective rights of national minorities and ethnic groups. In performing their original duties, the bodies of local self-government are completely independent, but within the reach of legal control of public administration (ministries). Delegated duties include all those tasks which are normally the responsibility of the state administration or of autonomous province, which the Republic of Serbia or autonomous province transfers to the local government unit for better performance. Carrying out these duties, local government bodies act as holders of state government (public authorities) towards the citizens. These duties include inspection activities in the area of 
education, health, environment, mining, trade in goods and services, agriculture, water and forestry and other inspection activities. In addition, not all local authorities need to be entrusted with the same jobs.

According to Article 13 of the Law on Local Self-Government, local government units can cooperate in order to achieve common goals, plans and development programs. They can also cooperate with local government units of other countries, in accordance with the Constitution and law. This fact has been especially true in recent years and is reflected in cross-border cooperation between Serbia and neighboring countries within the Euro-regions. A particular novelty in the law is Article 15 according to which selfgovernment has its own properties that govern in accordance with the law.

\section{Developmental capacity of local government units}

Every unit of local government in Serbia has a developmental capacity. The competitiveness of the local community is a synthesis of different types of capital which are at its disposal in relation to the other communities. The competitive advantage of specific local communities is reflected in its attractiveness and possibilities of new jobs, positive environment for investment and local entrepreneurship, the attractiveness of a place for residence, recreation and so on. Economic competitiveness involves the possibility of some local communities "participating, on an equal basis, in the market game" (Janković 2007). The investment climate affects the economic growth and new jobs. On the other hand, along with the economic development, adequate skilled workforce should be provided in the labor market.

A condition for socioeconomic progress of a local community involves the entry and application of new technologies, domestic and foreign direct investment, increased efficiency of human and material resources, and connecting the local economy with the economies of other regions within the Euroregions and other integrative processes. Besides the capital, those would bring modern technology, managerial skills, provide the export market, and promote the business of domestic enterprises. At the same time, the importance of the reforms of local institutions in order to raise the level of services to the citizens and businesses by reducing administration and increasing efficiency should not be overlooked.

The creation of competitive advantages of local government units and their positioning at the regional and national level are influenced by their social capital that involves the specifics of social organization, social norms, trust, quality and frequency of interaction, cooperation and mutual interest, 
distinctive local identity and transparency in the process of development (Jacobs 1961, Coleman 1988, Janković 2007, Vujadinović et al. 2010). As a unique resource of a local community, the social capital creates and maintains interpersonal relationships, connecting people through joint activities (Lee, Arnason et al. 2005; Shucksmith 2000; Cvejić 2004). The social capital can be seen as the coordination and cooperation aimed at joint profit (Putnam 1995) or the total of tangible and intangible resources that the social actors mobilize through membership in social networks (Bourdie, 1985) In the conditions of emphasized social inequalities and disparities in Serbia, the social capital "melts" (Petovar 2008). The social capital differs from the other forms of capital because it depends on the economic development of an area. The capacity of the social capital is limited only by imagination (Roseland, 2000). This means that every local community needs young, hardworking, ambitious people, entrepreneurs and managers whose sophisticated ideas will create a policy at the local level. The low level of the social capital leads to the deterioration of society at all levels of social organization. An increase in the social capital of local communities can be achieved in several ways (Putnam 1995, Blood 2006, Vujošević 2008), mostly through traditional forms of association, education system and the transfer of social values and norms, strengthening public safety and ensuring property rights and more.

Besides the social capital, an important element of development at the local level is participation. That is a positive interactive approach in which the population is motivated to participate in solving local problems, and the local government is ready and able to fulfill the needs and desires of the citizens whenever possible (Vujadinović et al, 2010). According to Pušić (2001), "participation is an indication of quality of life in a community. Local democracy does not exist by itself; it makes sense only to discuss it if it exists in a society as a whole, and in a society where the citizen is active. To be an active citizen, one must be interested. To be interested, one must be informed. To be informed, the system must be democratic. Although seemingly so simple and real, we know that there are societies which are far from the democratic processes, or only at their periphery, and that there are local communities that function without the participation of their citizens." The active participation of citizens in the public life of the local communities, according to Vukelić (2009), is reflected on the quality of life in that community and is considered one of the main conditions for the establishment of full democracy. Participation is a means of establishing the social dialogue as well as getting a consensus on developmental issues of the local community and the possible directions of joint action (Vujošević, 2008). Milošević (2005) 
points out that all the forms of citizen participation at the local level are equally important - informing, consultation (panels, public debates, online conferences), suggesting (citizens' meetings, petitions, individual suggestions, complaints, forms of public criticism, peaceful gatherings, demonstrations) and deciding (assembly of all citizens, referendum, citizens' initiative).

\section{Developmental problems at the local level}

The globalization of economic processes in combination with the transition process have brought most development issues to the local communities. As the main problems, we can single out the economic (high unemployment, low labor mobility, poverty, largely obsolete economy, unsuccessful privatization of the former economic giants), demographic (depopulation, the high average age of the population, a negative population growth and emigration of the young), social (unfavorable major social, cultural, educational and health indicators), infrastructural (related to communal and transport infrastructure) and environmental problems (related to waste, recycling, construction, reconstruction or closing of the landfills, reducing greenhouse gas emissions, etc.). All the mentioned problems complicate the work of local authorities, since in the past they mainly solved the problems of administrative and communal nature.

In Serbia, a disproportion in the development of local government units is present, as well as the process of deepening the present differences. The disproportion can be seen in the high concentration of population and industry in several cities and in demographic and economic stagnation in the other parts of the country. The slow process of the decentralization and the legal framework that prevents disposition of the property, make a deeper gap between the rich and the poor local government units. In that way, a centralized state makes the rich richer and the poor even poorer.

Research shows that in most local areas (municipalities), the largest problems are still unemployment and demographic problems, low living standard, infrastructural and communal problems.

Unemployment is the largest developmental problem in Serbia. In 2016 (second quarter) was a total of 495,500 unemployed persons in Serbia. Unemployment rate the population aged 15 and over is $15.2 \%$ for the whole of Serbia, with the highest value has in the region of Vojvodina (15.9\%) and lowest in the region of Sumadija and Western Serbia (14.6\%). The rate of youth unemployment from 15 to 24 years of age, the highest in the region of Vojvodina (38.8\%) and lowest in the Southern and Eastern Serbia (34.0\%) (Anketa 
o radnoj snazi, RZS). There is no regularity in the spatial distribution of municipalities with the highest unemployment rate, but its concentration is higher in the south-eastern part of Serbia, in the districts Toplički, Jablanica and Pčinjski. It is a homogeneous rural area characterized by a low population density, depopulation, intense process of aging, economic and infrastructural underdevelopment, modest natural resources and near the border position.

There is a high trend of negative population growth (-4.9\%o in 2014) and depopulation in Serbia, which resulted in a high aging index. All local government units recorded a negative population growth, except for the Belgrade municipalities Zemun and Zvezdara, Novi Sad and municipalities with a majority Muslim population (Sjenica, Tutin, Novi Pazar, Bujanovac and Preševo). The aging index is between 29.0 (Preševo) and 512.2 (municipality Crna Trava)(). The problems are especially numerous in the local communities where a high average age of the rural population dictates the establishment of new economic matrix in this region. Besides the unfavorable age structure of the population, other limiting factors of the development in these local communities are inadequate transport network, poor communal equipment of rural settlements and a very poor public network of social infrastructure, public disregard of demographic and economic problems of villages and a traditionally weak support of the development of agriculture. The economies of the most undeveloped and underdeveloped local communities are characterized by insufficiently developed entrepreneurial activity, which is unable to significantly absorb the surplus labor from the market. The slow process of restructuring the companies, lack of knowledge, managerial staff and new production technologies, low productivity and lack of financial resources for development, considerably complicate the harmonization of objectives of the local development with the regional developments.

The process of transition and switching from the centrally planned to a market economy increased the differences between the local government units regarding their socioeconomic characteristics. The present differences are largely a result of the inherited structure of the economy, which, in the conditions of transition, adjusted with more or less ease to the new economic and social developments. The Law on Local Self-Government and the Law on Local Government Finance foresee a reduction of the existing disparities. Almost every municipality in Serbia has started planning and implementing the projects for local economic development (LED). In this way, many of them became municipalities with a favorable business climate for domestic and foreign investors and donors, which is a basic condition of a gradual increase of the local development capacity. 


\section{Discussion}

\section{A critical review of the evaluation of the Law on Local Self-Government}

A analysis of the Law on Local Self-Government (Official Gazette RS, no. 129/07 and 83/2014) showed novelties that could positively influence the work of the local authorities in Serbia:

- the establishment of primary health care institutions is within the jurisdiction of municipalities,

- the new law foresees that a decision about establishing the cooperation, i.e. the conclusion of an agreement on cooperation with a local government unit from another country, should be adopted by the assembly of a local government unit, with the consent of the Government of the Republic of Serbia

- the concept of the city and the criteria for its establishment have been defined. The legal definition of the city and the criteria for its establishment did not exist in the previous laws on local government (the previous laws prescribed that the city is a territorial unit of local government established by law and on whose territory two or more municipalities are formed).

- cities are allowed to form the communal police

- the formation of urban municipalities in the territory of the city is not mandatory, and urban municipalities do not have the status of municipalities as local administration units. The law also foresees that the status of the City of Belgrade is defined by a special law (Law on the Capital City, Official Gazette RS, no. 129/07),

- the right of the municipality to manage its assets and

- the competence of local governments to adopt programs and implement projects of the local economic development and take care of the improvement of the general framework of economic activity in the local government units.

\section{Challenges for local governments}

The process of decentralization of government and strengthening the role of local government is slow. Encouraging the local economic development in the conditions of high unemployment and transitional poverty of 
the world economic crisis is difficult, and the implementation of the paradigm of sustainable development is insufficient in practice. In the further stages of decentralization, the unbalanced development of local government units will continue to be one of the fundamental problems of Serbia. How to overcome the existing situation in the country? Do the local authorities, besides the state, bear some responsibility for the situation at the local level?

The process of modernization of the state administration is still slow, and regulation of this area has a direct impact on the local level, especially when it comes to participation, the organization of government and business.

Participation is of marginal relevance in Serbia, and certain studies show that a high percentage of respondents $(67 \%)$ believe that the local authorities do not hear opinions of the citizens when making decisions (Milosavljević et al, 2006). On the other hand, participation is reduced to a minimum and is reflected in the apathy of most citizens, especially the young. Most local areas in Serbia are characterized by the problem of activism and mobility of young people. The young are not involved in decisionmaking processes, and most of them are indifferent to the current social trends. This situation is explained by the difficult economic situation that has lasted since the 1990s, so there are fewer and fewer optimists about the qualitative changes in the state economy.

Although the local policy is a cornerstone of democracy because it allows the greatest degree of participation, some of the characteristics of the organization of local authorities suggest hidden shortcomings. There is still a strong influence of political parties in decision-making system in the local government. Most commonly, the local representative bodies reflect the situation in terms of representation of the parties as it is the case in the national parliament, just as the local electoral systems generally follow the pattern established at the central level (Vučetić 2006, Marković 2009). The rule of particracy suppresses democratic processes in Serbia and represents a major obstacle to achieving the essential local government. The practice has shown that party affiliation (often in conjunction with nepotism) remains an important criterion of human resources policy at the local level. Thus, the political parties, while fighting for power, push the interests of the citizens of the local community into the background.

The quality and the way of operation of the administrative bodies in the local communities are very important because they have direct contact with the citizens. However, it is difficult to change the management philosophy in Serbia. Administration as a authoritarian system of administrative 
decision-making (the citizens are objects and subordinate subjects), is slowly changing into the government as a public service and the service of citizens, where citizens should have the central position as the users of administration services. The citizens' trust in the institutions of local government is very small, and has not significantly changed after 2000 . The local authorities, even 10 years later, failed in establishing the essential trust between the local government and the citizens. In terms of particracy, the local communities often do not function in the interest of their members, and the social capital or the relations in the community, are reduced to a minimum or non-existent. Therefore, there are difficulties in encouraging the population to take some responsibility for the progress of the community (municipality, city). The administration usually considers the citizens as incompetent and indifferent to the problems of the local community, whereas the citizens perceive the administration as an alienated, and often corrupt body indifferent to their life problems. This important two-way communication must be based on information and education. Precisely the idea of participation has the point at the local level, because each of us experiences their primary local environment very directly. At the same time, a direct interest and motivation of individuals to solve the problems and the needs of the area. Meanwhile, it is easiest to implement the suggested solutions at the local level and see their concrete results. Nowadays a large part of the administrative and executive tasks is simplified by the introduction of information technology (IT one stop shop centers), thereby shortening the procedures and enabling the citizens to perform transactions. These processes are in infancy in Serbia but where these solutions were applied, the results were good. However, Serbia still has local governments without a computer, and a great obstacle are the project forms that require expertise and perfect English. In order to attract EU funds besides the money both informational support and knowledge are required. That is why the developed local government units receive most foreign direct investment because not every municipality in Serbia has the appropriate means and good quality of skilled personnel to meet the strict requirements of the foreign investors.

\section{Conclusion}

The issues related to local government in the circumstances of still centralized countries such as Serbia, are gaining more and more importance. The existing tendency of economic strengthening of Belgrade, with the weakening of other parts of Serbia, can be stopped by the fundamen- 
tal decentralization of the country and by the efficient work of the local authorities. The municipalities and cities must use the forthcoming reforms to strengthen their developmental capacity in order to perform a set of important tasks successfully, without which a modern society can not function. The basic interest of the local authorities must be provision of services to the citizens in order to solve the problems and satisfy their needs, which constitutes the basic content of a socially responsible development. A balanced development of Serbia involves local actors of government taking over the initiatives and responsibilities for the development of the areas they govern. The condition of decentralization is restoring the property to local governments and the full fiscal decentralization The key drivers of supporting activities for economic growth and development and increasing competitiveness of the local economy are the local government units. Improving the position of the local economy of municipalities in the national and global economy is the main goal of increasing the competitiveness of the local economies. In the conditions of modest and limited resources at the local level, as is the situation in most municipalities, it is necessary to find the optimal combination of available resources with the possibilities offered in the given socio-economic circumstances. The specific measures of local government may be aimed at encouraging investment and attracting domestic and foreign direct investment as well as the creating the favorable business conditions for enterprises.

Unfortunately, the majority of factors on which the growth, development and competitiveness of the local areas depend are still in the domain of the republic or province governments, and only a small number depends on the local government. The reform of legislation creates the conditions for better functioning of local governments. On the other hand, the negative experiences of the functioning of local authorities should be overcome in the future, especially in order to strengthen the social capital, raise the level of transparency in work and increase the citizens' participation. To valorize numerous and diverse but still insufficiently exploited natural and economic potentials of underdeveloped local governments, a priority objective of economic development should be encouraging investment and attracting domestic and foreign capital.

Numerous developmental problems at the local level require the construction of a value system that will encourage each unit of local government and the individual to turn toward themselves, to earn money so that poverty or social problems are not seen as the expression of virtue and honesty, which is often the practice in Serbia. The solution of existing problems in the relations between the local government and the state can only be achieved 
by establishing the right balance between the central republic jurisdiction on the one side, and local autonomy, on the other side.

\section{Acknowledgements}

The paper is the result of the research within the project no. 176008 funded by the Ministry of Education and Science of the Republic of Serbia

\section{References}

Anketa o radnoj snazi, II kvartal 2016. RZS. http:/ / webrzs.stat.gov.rs/WebSite/repository/documents/00/02/23/91/RS10-227-ARS.pdf

Begović, B. et al. (2006). Lokalni ekonomski razvoj, Centar za liberalnoekonomske studije i Stalna konferencija gradova i opština, Beograd.

Belkić, V. et al. (2010). Lokalni ekonomski razvoj-evropski putokaz ka modernoj lokalnoj samoupravi, Građanska mreža, Beograd.

Blagojević, S. M. (1997). Lokalna samouprava u teoriji, komparativnom iskustvu i praksi. Lokalna samouprava Niš, 2, 14-15.

Bourdieu, P. (1985). The Forms of Capital, In Richardson, J.G. (Ed), Handbook of Theory and Research for the Sociology of Education. Greenwood, New York.

Coleman, J. S., (1988). Social capital in the creation of human capital. American Journal of Sociology, 94, 95-120.

Cvejić, S. (2004). Građanski pokret, socijalni kapital i institucionalna transformacija u post-socijalističkoj Srbiji, Sociologija XLVI (3).

Davitkovski, B. (1997). Lokalna samouprava - pojam i elementi. Lokalna samouprava Niš, 1, 22-23.

Dimitrijević, P. J. (1999). Odnosi republičkih organa i organa jedinica lokalne samouprave. Lokalna samouprava Niš, 5, 210.

Đurđev, A. (1997). Lokalna Samouprava, Pravni fakultet, Centar za izdavačku delatnost, Novi Sad, 2. Goldsmith, M. (1990). Local autonomy: Theory and practice. u: Challenges to Local Government, SAGE

Ilić, M. (1996). Lokalna samouprava u Jugoslaviji. Niš, Gradina.

Jacobs, J., (1961). The Death and Life of Great American Cities, Random House, New York. 
Jacobs, M., (1993). The Green Economy: Environment, Sustainable Development, and the Politics of the Future, University of British Columbia Press, Vancouver.

Jacobs, M., (1997). The new politics of the environment. In: Jacobs, M. (Ed.). Greening the Millennium? Blackwell Publishers, Oxford.

Janković, D. (2007). Importance of social capital in the development of local rural communities, Zbornik Matice srpske za društvene nauke, 123, 173-190.

Jovanović, J. et al. (2011). Jačanje lokalne samouprave u Srbiji, faza 2, Najbolja praksa u lokalnim samoupravama u Srbiji. Priručnik studije slučaja, Savet Evrope, Beograd.

Kuzmanović, R. (1999). Pluralna ili monotipska organizacija lokalne samouprave. Lokalna samouprava Niš, 5, 13-14

Lee, J, Árnason, A, et al. (2005). Networking: Social Capital and Identities in European Rural Development, Sociologia Ruralis, 45(4), 273.

Lilić, S. L. (1999). Lokalna samouprava u Srbiji i Crnoj Gori - normativni aspekti. Lokalna samouprava Niš, 5, 128.

Louglin, M. (1996). Legality and Locality: The Role of Law in Central Local Government Relations. London, 82.

Milosavljević, B. (2005). Sistem lokalne samouprave u Srbiji, Stalna konferencija gradova i opština, Beograd.

Milenković, D. (2000). Ustavni i zakonski okviri odnosa lokalne samouprave i centralne uprave u Srbiji. Pravni život Beograd, 49(7/8), 37-46.

Milosavljević B, Popadić, D. i Logar, S. (2006). Učešće građana na lokalnom nivou - Analiza pravnog okvira i politike u Srbiji i drugim evropskim zemljama, Stalna konferencija gradova i opština, Beograd.

Milosavljević, B. (2009). Sistem lokalne samouprave u Srbiji, Beograd: Stalna konferencija gradova i opština.

Milovanović, D. M. (1994). Pravno ustrojstvo lokalne samouprave. Beograd: Pravni fakultet

Mirić, O. (2009): Regionalna politika Evropske unije kao motor ekonomskog razvoja, Evropski pokret u Srbiji, Beograd.

Mujović, R. (1997). Evropska povelja o lokalnoj samoupravi i naša lokalna samouprava. Lokalna samouprava Niš, 2, 25-27. 
Ostrom, E. (1993). Social Capital and Development Projects. Unpublished paper prepared for workshop "Social Capital and Economic Deveopment," American Academy of Arts and Sciences, Cambridge, MA, 30-31 July 1993.

Opštine i regioni u Republici Srbiji, RZS, Beograd, 2015. Pajvančić, M. (1999). Pravo građana na lokalnu samoupravu. u: Bubalo Ratko (ur.) Građanin u pravnom sistemu SR Jugoslavije, Beograd: Helsinški odbor za ljudska prava u Srbiji, 177

Pavlović Križanić, T. (2010). Priručnik za strateško planiranje i upravljanje lokalnim razvojem u Roseland, M.(2000): Sustainable community development: integrating environmental, economic, and social objectives, Progress in Planning, 54, 73-132.

Petovar, K. (2008). Teorijski i metodološki pristup za koncepciju socijalnog razvoja Zlatiborskog regiona, Novi teorijski i metodološki pristupi u izradi strategije održivog regionalnog razvoja, Primer Zlatiborskog regiona, Centar za demokratiju, Institut za arhitekturu i urbanizam Srbije, 69-82.

Petrović, M. (2003). The Essence of Regions - with a Particular View of the Latest Kinds of Regionalization: Scotland, Wales and Northern Ireland in the United Kingdom of Great Britain and Northern Ireland. Facta Universitatis Series: Law and Politics, 1(7), 747

Putnam, R., Leonardi, R., Nanetti, R., (1993). Making Democracy Work: Civic Traditions in Modern Italy, Princeton University Press, Princeton.

Putnam, R.D., (1995). Bowling alone: America's declining social capital. Journal of Democracy, 6(1), 65-78.

Pušić, Lj. (2001). Održivi grad. Beograd, 317.

Roseland, M. (2000). Sustainable community development: integrating environmental, economic, and social objectives. Progress in Planning, 54, 73-132

Shucksmith, M. (2000). Endogenous Development, Social Capital and Social Inclusion: Perspectives from LEADER in the UK, Sociologia Ruralis 40, (2).

Tomić, Z. (2002). Upravno pravo - sistem (4 izdanje). Beograd, str. 205

Vučetić, D. (2006). Decentralizacija kao polazište daljeg razvoja Srbije: priručnik/Dejan Vučetić, Dejan Janićijević. - Niš: Centar za razvoj građanskog društva "Protecta", 2006 Vujadinović, S. et al. (2010). Integral sustainable development: the example of local geographic milieu. Bulletion of the Serbian Geographical Society, 90(2), 181-187. 
Vujošević, M. (2008). Kratak opis ideje održivog razvoja, Novi teorijski i metodološki pristupi u izradi strategije održivog regionalnog razvoja, Primer Zlatiborskog regiona, Fond Centar za demokratiju, Institut za arhitekturu i urbanizam Srbije.

Vujošević, M. (2008). Primena participacije u pripremanju, donošenju i ostvarivanju dokumenata održivog razvoja-teorijski i metodološki aspekti. Novi teorijski i metodološki pristupi u izradi strategije održivog regionalnog razvoja Primer Zlatiborskog regiona, Fond Centar za demokratiju Institut za arhitekturu i urbanizam Srbije.

Vukelić, J. (2009). Neposredno učešće građana u donošenju odluka na lokalnom nivou vlasti u Srbiji, Institut za sociološka istraživanja Filozofski fakultet Univerzitet u Beogradu.

Nacionalna strategija održivog razvoja Republike Srbije. Vlada Republike Srbije, Beograd 2008.

Savet Evrope (1989). Evropska povelja o lokalnoj samoupravi. Komuna, Beograd, 7-8, 44-46.

Strategija regionalnog razvoja Republike Srbije 2007-2012. godine, Službeni glasnik Republike Srbije, br. 21/07.

Uredba Vlade Republike Srbije o utvrđivanju jedinstvene liste razvijenosti regiona i jedinica lokalne samouprave za 2011. godinu, Službeni glasnik Republike Srbije, br. 69/11.

*** (2007) Zakon o teritorijalnoj organizaciji Republike Srbije, Službeni glasnik Republike Srbije, 129/07.

*** (1999) Zakon o lokalnoj samoupravi. Službeni glasnik Republike Srbije, br. $49 / 99$.

*** (2002) Zakon o lokalnoj samoupravi. Službeni glasnik Republike Srbije, br. 9/02.

*** (2007) Zakon o lokalnoj samoupravi. Službeni glasnik Republike Srbije, br. $129 / 07$

*** (2006) Zakon o finansiranju lokalne samouprave, Službeni glasnik Republike Srbije, br. 62/06.

*** (2011) Zakon o finansiranju lokalne samouprave, Službeni glasnik Republike Srbije, br. 47/11. 